Фаріон, Ірина. «Про ім’я Ева: адаптація, ідентифікація, мотиви». Лінгвостилістичні студії, вип. 10, 2019, c. $186-194$.

Farion, Iryna. "The Name of Eva: Adaptation, Identification, Motives". Linguostylistic Studies, iss. 10, 2019, pp. 186-194.

Удк 81'373.23/231(=411.16)

https://doi.org/10.29038/2413-0923-2019-10-186-194

\title{
ПРО ІМ'Я ЕВА: АДАПТАЦІЯ, ІДЕНТИФІКАЦІЯ, МОТИВИ
}

\author{
Ірина Фаріон \\ Національний університет «Львівська політехніка», \\ Львів, Україна
}

У статті розглянуто походження та адаптацію старожидівського імени Ева на основі перших і найдавніших перекладів Біблії українською мовою. Розкрито етимологію імени, його фонетико-морфологічну, словотвірну адаптацію та низку похідників в інших класах антропонімійної лексики. Зазначений антропонім проаналізовано на тлі інших старожидівських запозичень, що, пройшовши через докорінну фонетико-словотвірну адаптацію на українському грунті, стали українськими національними ідентифікаторами.

Ключові слова: антропонім Ева, адаптація антропонімійної лексики, національна ідентифікація, мотиви називання, суспільна рецепція.

Farion Iryna. The Name of Eva: Adaptation, Identification, Motives. The issue of the origin and adaptation of the anthroponymic vocabulary in the Ukrainian language is of exceptional importance in terms of their both political and purely linguistic nature. It is the synthesis of the extralinguistic and intralinguistic factors, that allows anthroponymic vocabulary disclose the political course of the nation and reveal the language capacity to transform the borrowed material, adopt it to its own purposes and assert it as native.

The subject of this research is a symbolic biblical Old Hebrew name Eva analezed from the standpoint of the Ukrainian socio-historical processes, with an emphasis on the perspective of clarifying its public perception, the reasons for naming, phonetic and wordformation adaptation to the national Ukrainian linguistic tradition.

The purpose of the article is to reveal the sources of borrowing the name Eva and its functioning in the first symbolic biblical Ukrainian texts; to identify its uniqueness among other commonly used names of Old Hebrew origin; to analyze phonetic and morphological and word-formation adaptation of this name as newly-acquired Ukrainian identification; to elucidate the reasons for naming and the peculiarities of the public perception of this biblical name.

Thus, the Old Hebrew names (20\%, or one fifth of our active anthroponymycom), mostly in Old Slavonic (later in Church Slavonic), have completely "melted" in the "furnace" of our language and became signs of our self-sufficient culture and identity. It is evidenced by their phonetic and morphological form, word-formation structure and the number of derivatives in different layers of the onym vocabulary, from anthroponyms to toponyms, oikonyms, etc.

\footnotetext{
(C) Фаріон І., Східноєвропейський національний університет імені Лесі Українки, 2019.

Це стаття відкритого доступу на умовах CC BY-NC 4.0
} 
It is absolutely pointless to associate the long ago adapted in our language Old Hebrew names with the ethnicity of any person. Such commonly met public perception is a demonstration of political manipulations, confined social thought, lack of knowledge about the laws of foreign anthroponymic substratum functioning in our language.

Key words: anthroponym Eva, adaptation of anthroponymic vocabulary, national identification, reasons for naming, public perception.

Ми не перестаємо бути українцями тільки через те, що маємо грецькі, латинські та ін. імена.

Ізмаїл Срезневський

Вступ. Проблема походження та адаптації антропонімійної лексики в українській мові має виняткове значення з огляду як на політичний, так і суто мовний характер. Себто йдеться про показовий синтез позамовних та внутрішньомовних чинників, що через антропонімійну лексику виявляють політичний курс нації та мовну спроможність трансформувати у власних цілях запозичений матеріял і видавати його за «свій». Сучасні українські антропонімісти зазвичай аналізують структурно-семантичний, діяхроннотериторіяльний, стилістичний та соціолінгвальний контекст антропонімійної лексики, що відображено передусім в українській антропонімічній класиці (Керста; Осташ; Сенив; Фаріон, «Ідентифікаційна»; Масенко; Белей, «Про соціальне»).

Предметом нашої розвідки є знакове біблійне старожидівське ім'я Ева як фокус українських суспільно-історичних процесів крізь призму з'ясування його суспільної рецепції, мотивів називання, фонетикословотвірної адаптації та національної ідентифікації на українському мовному грунті.

Мета статті - розкрити історію питання, себто джерела запозичення імени Ева та його функціювання в перших і знакових біблійних українськомовних текстах, а також серед інших поширених сьогодні імен старожидівського походження загального вжитку; проаналізувати фонетико-морфологічну та словотвірну адаптацію цього імени як новонабутої української ідентифікації; розкрити мотиви називання та особливості суспільної рецепції цього біблійного імени.

Джерельною базою нашого дослідження $\epsilon$ вживання імени Ева $(\epsilon в a)$ в чотирьох знакових перекладах Біблії українською мовою 1903 року (переклад, П. Куліша, I. Пулюя, I. Нечуя-Левицького), 1962 року (переклад митрополита Іларіона (I. Огієнка), 1963 року (переклад о. І. Хоменка), 2006 року (переклад Острозької Біблії 1581 року від о. Р. Турконяка), а також фіксація цього антропоніма в основних антропонімійних лексикографічних джерелах (Трійняк 118; Скрипник, і Дзятківська 136; Костів 135; Janowowa, Zaręba, 93).

Щоб розкрити походження та структуру цього антропоніма, застосовуємо метод етимологічного та словотвірного аналізу; метод кількісних підрахунків використовуємо 3 метою з'ясувати загальну 
кількість функціональних імен у сучасній українській мові старожидівського походження; 3 допомогою соціолінгвального методу розкриваємо мотиви номінації та суспільну рецепцію імени.

\section{Виклад основного матеріялу.}

Історія питання. Наші імена - це найпоказовіша історія взаємин 3 іншими народами та культурами. Першим священним джерелом проникнення цього імени в нашу культуру стала Острозька Біблія (1581 року), щойно 2007 року перекладена українською мовою від Рафаїла Турконяка. Характерно, що первісно це ім'я подано в українському буквальному перекладі як Життя: «І назвав Адам ім'я своєї жінки Життя, бо вона матір всіх живих» (Глава 3.20) (Острозька Біблія 19), а відтак вже у главі 4 вперше читаємо це ім'я в питомій старожидівській формі, але в українській адаптації Ева: «Адам же пізнав Еву, свою жінку, і зачавши, породила Каїна» (Острозька Біблія 19). У такій самій формі вжито це ім'я і в першому перекладі Біблії українською мовою 1903 року І. Пулюя, П. Куліша, I. Нечуя-Левицького: «I дав чоловік жіньці своїй імя Ева: бо вона мати всіх живих», «І взнав чоловік Еву, жінку свою, і завагонївши вона, вродила Каїна» (правопис збережено) (Голова 3.19, 4.1.) (Сьвяте Письмо 7). У наступних перекладах I. Огієнка (1962р.) та I. Хоменка (1963р.) це ім'я вжито в йотованому фонетичному варіянті: «І назвав Адам ім'я своїй жінці: $\boldsymbol{\epsilon в а , ~ б о ~}$ вона була мати всього живого» (Біблія або Книги 12); «Тоді Адам дав своїй жінціім'я $\boldsymbol{\epsilon в а , ~ б о ~ в о н а ~ б у л а ~ м а т и ~ в с і х ~ ж и в и х » ~ ( Б і б л і я ~ 6 ) . ~ С е б т о ~ е т и м о л о г і ч н о ~}$ це 'життя, жива' (ст.-жид. ім. Наuйā < haįā 'жива' (Трійняк 118): «...правдоподібно, спільне родове ім'я для позначення самого життя. У Книзі Буття $\boldsymbol{\epsilon в а ~ у о с о б л ю є ~ м а т е р и н с т в о , ~ з н о в у ~ Н о в и и ̆ ~ З а п о в і т ~ н а г о л о ш у є ~ і ̈ і ~}$ гріхопадіння в Едені, коли то змій лукавством звів їі й вона перша порушила Божу волю. <...> Таким чином гріх увійшов у світ. Крім Каїна, Авеля й Сифа, в Адама та Єви були ще інші сини й дочки. <...> Біблія дуже мало говорить нам про життєвий шлях Єви після вигнання з Едену й ми нічого не знаємо про їі смерть» (Костів 135).

Біблія дуже поступово й повільно входила в наше українське життя. Християнство ми приймали кількома хвилями винятково як політичнодержавницький акт ще від часів Аскольда (його убив Олег, імовірно, 3 намови язичників 882 року). Відтак щойно 1903 року ми отримали перший переклад Біблії, на який вище й покликаємося. На першому Нікейському соборі 325 року канонічно визначено, що християнам під час хрещення дають імена християнських святих, які, звісно, що мали чужомовне походження. У східних слов'ян до вживання християнських імен почали масово переходити з кінця X століття, тоді як у західних - аж із кінця XVI століття відповідно до рішення Тридентського собору (15451563 рр.) (Медвідь-Пахомова 299). Нові імена-антропоніми, як знаки перейнятої культури, найпотужніше вриваються в наш простір із середини XIII століття, про що зауважує Іван Франко: «Грецькі, латинські, а потрохи і жидівські імена власні переняло християнство в свій календар і розширило 
їх по всьому світі як хресні імена; вони витиснули відповідні індивідуальні поганські (у нас слов'янські) імена і своєю чергою послужили в модифікаціях, відповідних духові кожного язика також для витворення цілого ряду родових прозвищ» (Франко 392). Ці імена в нас сьогодні називають «візантійськими християнськими іменами, або іменами християнського календаря» (Скрипник, і Дзятківська 7), фонетико-морфологічне та словотвірне засвоєння яких у нашій мові на XVI століття можна вважати доконаним фактом. Саме тоді християнські імена, зокрема старожидівського походження, на нашому грунті поглиблюють свою специфічну фонетикоморфологічну й словотвірну адаптацію.

Азарій'Ягве (бог) допоміг' $\rightarrow$ Азарко, Зарко, Зарцьо, Озарко;

Гаврило 'моя міць, могутність - Бог' $\rightarrow$ Аврик, Габор, Габрик, Гаврилко, Гавришко та ін.;

Данило 'мій суддя - Бог', 'божий суд’ $\rightarrow$ Данилко, Даньо, Данилещь, Данильчик та ін.;

Ілля 'Ягве - мій Бог' $\rightarrow$ Гилько, Єлько, Єльчик, Ілейко, Ільцьо, Ільчик, Ілюсик та ін.;

Йосип(ф), Ocun 'він (Бог) примножить, додасть' $\rightarrow$ Йосько, Йосюньчик, Йосипко, Йоня, Юсик та ін.;

Михайло 'хто як Бог, рівний Богові' $\rightarrow$ Михась, Місьо, Мишко, Михасик, Михайлик, Мисечко та ін.;

Назар 'присвятив себе Богові' $\rightarrow$ Назаречко, Назарчик, Назаруньо, Назарко та ін.;

Охрім і Єфрем 'плідний, урожайний' $\rightarrow$ Охрімщьо, Охрімчик, Охрімочко, Охрімик та ін.;

Семен 'Бог чує' $\rightarrow$ Сень, Сеник, Сенько, Сенечко, Семесь та ін.;

Соломія і Саломея 'мир', 'спокій', 'благополуччя' $\rightarrow$ Соля, Солька, Соломашка, Солося та ін.;

Тамара 'фінікова пальма' $\rightarrow$ Марця, Мася, Тамонька, Томця, Томонька та ін.;

Хома (Фома) 'близнюк' $\rightarrow$ Томаш, Томцьо, Хомичко, Хомчик, Хомонька та ін.;

Ярема, Веремій, Єремія, Ієремія 'Ягве (Бог) піднесе, возвеличить' $\rightarrow$ Яремик, Яремцьо, Яремійко та ін.

Звернімо увагу, що більшість жидівських імен мають характерне богоносне (теофорне) значення, тобто в своїй етимології містять назву Бога. Таку модель запозичили греки й римляни, як кальки виникли вони і в нас на зразок Богдан (Феодор), Богухвал, Богумил, Богуслав (Супераская 32-34).

Адаптація як національна ідентифікація. Через фонетикоморфологічну та словотвірну адаптацію чужі імена стали в нас символами нашої культури: чуже та питоме злилося й дало новий вицвіт саме з нашої

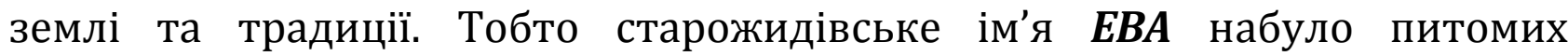
зменшено-пестливих (демінутивних) та згрубілих (авгментативних) 
суфіксів, що $є$ визначниками винятково української мови: Евка, Евонька, Евочка, Евуня, Евуся, Евуська, Евця; Єваха, Євисько, Євище, Євка, Євонька, Євочка, Євуля, Євунька, Євуня, Євуньия, Євусенька, Євуся, Євуха, Євушка, Євия, Євчатко, Євчище; Їва; Явка, Явочка (Трійняк 118). Адаптація та продуктивність уживання цього імени такі високі, що ім'я стало основою для творення прізвищ з характерними українськими суфіксами переважно патронімно-матронімного значення: Єва, Євенко, Євенок, Євенчук, Євещь, Євик, Євин, Євич, Євківський, Євко, Євочка, Євусяк, Євушко, Євчак, Євчан, Євченко, Євчик, Євчин, Євчинець, Євчук, Євчун, Явиха, Явкун (слушно, що

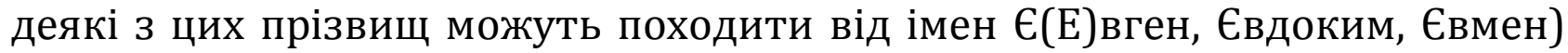
(Трійняк 118).

Звернімо увагу, що сучасні найпоширеніші словники подають це ім'я 3 початковими варіянтними $\mathbf{E}$ та $\boldsymbol{\epsilon}: \boldsymbol{E}_{в a}$ та $\boldsymbol{\epsilon}_{в a}$ (Трійняк 118) або тільки $\boldsymbol{\epsilon}_{в a}$ (Скрипник, і Дзятківська 136), тоді як перший соборний академічний український правопис 1929 року каже лише про початкове е: «У чужих словах на початку слова $\boldsymbol{e}$ віддаємо через $\boldsymbol{e}$ (а не $\boldsymbol{\epsilon}$ ): напр., Европа, европеєць, європейський, Ефрат, Евпаторія, Еспанія...» (Осипів 21). Показово, що для абсолютної більшости мов світу характерний нейотований варіянт цього імени $E в a$, а не $\epsilon в a$. Відповідно до джерела, йотований варіянт цього імени серед 27-х мов побутує в литовській, в.-лужицькій мові, паралельні варіянти подано в латиській мові і, на жаль, зовсім усупереч практиці уживання, подано це ім'я як Ева в російській мові та $Є в a-$ в українській, де існують два фонетичні варіянти (Janowowa, Wanda, Zaręba, 93).

Отже, ідентифікація «не тільки розділяє, але і вводить у ряд. Ім'я пов'язує носія з іншими носіями цього самого імени, із тою самою групою суспільства, в якій воно прийняте, незалежно від його вихідного етимологічного значення» (Никонов 13-14).

Нагадаю, що в сучасній українській мові функціює близько 600 чоловічих та понад 450 жіночих імен, серед яких 119 старожидівських (Трійняк; Скрипник, і Дзятківська), на понад 40 мільйонів українців, тоді як у давньому Римі обмежувалися лише 18 іменами, але, як зауважує А. Коваль, усі рекорди побили шведи: у них 6 чоловічих і 6 жіночих імен охоплює третину жителів країни (Коваль 54). Проте майже скрізь найпопулярнішим (у святцях східної церкви трапляється аж 170 разів (Белей, Ім'я для дитини 15)) є інше старожидівське ім'я Іван (ст.-жид. İohānān, İěhōhānān 'Ягве (бог) змилосердився, помилував - божа милість, божа благодать' (Трійняк 143), що існує в різному одязі винятково своїх мов: у фр. Жан, англ. Джон, нім. Йоганнес (Ганс), сканд. Юхан, есп. Хуан, італ.Джованні, пол. і чес. Ян, молдов.Іво та ін. Натомість жіноче старожидівське ім'я Ганна (рід. Анна), що походить від Channa<chanan 'він (Бог) був милостивий, виявляв ласку' - 'лагідна, милосердна, мила', $є$ найпопулярнішим у світі: його має близько 95000000 жінок нашої планети (Трійняк 81). 
Отже, національномовна адаптація антропоніма - це один із надійних засобів ідентифікації народу: якщо я Іван, а не Йоган, то я українець; а якщо я Ваня, то Івасик - людина іншої етноналежности. I що це за українка Ганна, обізвана Аннушкой, Анічкой, а Марія (ст.-жид. Miriām<mārar 'бути гірким гірка'; або ст.-жид. mārā 'чинити опір’, 'відмовлятися', 'заперечувати - яка чинить опір, заперечує; вперта' (Трійняк 212) (згадайте упертий і зухвалий характер героїні Лесі Українки Міріям з поеми «Одержима»), обізвана Машей, Мурачькай, Машулєй? Набувати чужих форм імени - це уподібнюватися до чужої нації. Саме звідси імператив від видатного українського мовознавця Івана Огієнка: «Бережи своє особове ім'я й родове прізвище в повній національній формі й ніколи не змінюй їх на чужі. I найменша тут зміна - крок довинародовлення». Отже, національна форма імени, себто передусім фонетична оболонка, всупереч джерелові походження самого імени, стає ідентифікацією носія. Так само неминучі запозичення в мові свідчать передусім про ії̈ здатність переробляти чужий матеріял на свій лад.

Ім'я як універсальний знак - це водночас мовно-національний витвір, і визначальну роль у цьому відіграють суфікси як найкраща візитівка щодо мовної, а тим самим і етногенетичної належности носія власної назви (Rospond 32). Саме вони, суфікси, є інформаційно-національними кодами антропоніма. Ми сильні не тим, що не запозичуємо, а тим, що дуже вправно адаптовуємо, хоча віддаємо належне слушній думці I. Пачича: «Я роздумував із собою, що ми упродовж декількох століть, уживаючи чужі для нас халдейські, жидівські, грецькі, латинські, німецькі імена, які ми не розуміємо, можемо зіпсувати свою народність... Чому нам не повернутися до своїх давніх імен і не почати називатися ними?» (Пачичъ). Як зауважує видатний український ономаст П. Чучка, кількісне співвідношення слов'янських (питомих, або автохтонних) імен та імен іншомовної етимології (походження) в сучасних слов'янських народів дуже різне. У південнослов'янських народів питомі імена сягають понад 70\%, у чехів приблизно 30-35\%. Натомість в українців питомі імена на зразок Ярослав, Людмила, Віра (калька з грецької) - всього лише 3-4\% (Чучка 10). До речі, П. Чучка у своєму знаменитому словникові реконструював понад 2000 тисячі таких питомих українських імен. Додамо, що в поляків, попри могутній вплив католицизму, сума християнських імен відповідає питомим (автохтонним), таке ж співвідношення спостережено в босняків, чорногорців, далматинців, словаків і лужичан (Фаріон, «Вплив християнства» 309).

Для усвідомлення глибини нашої мистецької мовної адаптації пропоную перелік усіх найпоширеніших імен старожидівського походження за основними сучасними і дієвими джерелами (Трійняк, Скрипник, і Дзятківська). Їх є 119 із понад 600 сьогодні активних імен, себто п'ята частина, або $20 \%$ :

Аарон, Авдієс, Авдон, Авель (Абель), Авенір, Авесалом, Авив, Авим, Авія, Аврам (Оврам, Абрам), Ада, Адам, Аза, Азарій, Амон (Амоній), Амоніт, Амос, 
Ананій, Аріян, Асир, Ахаз, Ахія; Бал(ь)тасарій; Варак, Варахіїл, Варахісій, Варух, Веніямін, Віфоній; Гаврило, Гад, Ганна (Анна), Гедсон, Голіяф, Гурій; Давид, Дан, Данило, Діна; Естера (Есфір), Ева (Єва); Єзекія, Єлизар (Єлеазар), Єлима, Єлисей (Ялисей), Єнафа, Єрусалим; Іван, Ієгудиіл, Ієзекіїль (Єзекіїль), Ієгудиїл, Ієсей, Ізабелла, Ізмаїл, Ілій, Ілля (Ілько), Іоад, Іов (Йов), Іоїла (Іойль), Іона (Йона), Іордан (Йордан), Іосій (Іосія), Ісав, Ісай, Ісак (Ісаак, Сакій), Iсахар, Іуда (Юда); Йосаф, Йосафат (Ocафат, Сафат), Йосип (Ocun, Йосиф); Каїн; Лазар, Левій; Манасій, Манефа, Мануїл, Марія, Мелхиседек, Мельхіор, Михайло, Михей, Мусій (Мойсей); Назар, Наум, Нафан, Невфалим, Неємія; Огій (Огей), Ольда (Олдама), Осія, Охрім (Ефрем); Рувим, Руф; Саватій, Савел (Савелій), Самей, Самон, Самсон, Саул, Семен, Серафим, Серафима, Сим, Симон, Сисой, Сіоній, Соломія (Саломея), Соломон, Софон, Сусанна; Тамара; Фафуїл; Халев, Хома (Фома); Юдита (Юдиф); Яків, Ярема (Веремій, Єремія).

Мотиви називання та суспільна рецепція - це дуже мінлива ірраціональна сфера, проте варто пам'ятати саме глибинну й класичну мотивацію, а не ту, що виникає на гребені модної минущої хвилі чи просто загальної необізнаности суспільства 3 ономастикою, що в перекладі 3 грецької означає «мистецтво давати імена». На думку Платона, давати їх можуть не всі, а лише майстри своєї справи. Сама ж майстерність полягає в здатності осягати сутність речей, які і промовляють з імени. Отож, до класичних мотивів номінації належать родина традиція, за якою сина або доньку називають іменем батька, дідуся, бабусі, матері та інших родичів; вшанування іменем дитини видатних осіб, літературних та кіногероїв тощо; милозвучність імени та його легкість і стислість вимови (Скрипник, і Дзятківська 12). Завше серед національно свідомих батьків працюватиме мотивація назвати дитину так, щоб неможливо було змосковщити ії ім'я, як, до прикладу, EBA чи грецьке ім'я Тарас.

Висновки та перспективи дослідження. Отож, старожидівські імена (20\%, або п'ята частина нашого активного антропонімікону), зазвичай у старослов'янській (згодом у церковнослов'янській) одежині, сповна переплавились у горнилі нашої мови і стали знаками нашої самодостатньої культури та ідентичности, про що свідчить їхня фонетикоморфологічна форма, словотвірна будова та низка похідників у різних пластах онімної лексики: від антропонімів до топонімів, ойконімів та ін.

Абсолютно безглуздо пов'язувати давньожидівські, давно адаптовані в нашій мові імена з етнічністю тієї чи тієї людини. Така непоодинока суспільна рецепція $\epsilon$ виявом політичних маніпуляцій, примітивности суспільної думки й необізнаности з законами функціювання чужомовних антропонімних основ у тканині нашої мови. Подальше дослідження окремо взятих знакових антропонімів уможливить сконструювати українську антропонімну будівлю, що, базуючись на запозичених основах, набула своїх, питомих надбудов та обрисів і стала знаком національної тожсамости. 


\section{Список використаних джерел}

Скрипник, Лариса, і Дзятківська, Ніна. Власні імена людей. Київ, 1996.

Сьвяте Письмо Старого і Нового Завіту. Переклад П. Кулїша, І. Левіцького, та І. Пулюя. Ню Йорк: Американське біблійне товариство, 1944.

Біблія або Книги Св. Письма Старого та Нового Завіту. Переклад Івана Огієнка. ВБФ «Східноевропейська місія», 2018.

Костів, Кость. Словник-довідник біблійних осіб, племен і народів. Київ, 1995.

Острозька Біблія. 2-ге вид. Опрацював та приготовив до друку єрмнх. архімандрит Рафаїл (Роман Турконяк). Львів, 2010.

Трійняк, Іван. Словник українських імен. Київ, 2005.

Біблія. Святе Письмо Старого та Нового Завіту. Переклад тексту о. Івана Хоменка. Видавництво Василіян: Місіонер, 2007.

Janowowa, Wanda, Zaręba, Alfred. Słownik imion. Wrocław, 1991.

\section{Sources}

Skrypnyk, Larysa, and Dziatkivska, Nina. Vlasni imena liudei. Kyiv, 1996.

Sviate Pysmo Staroho i Novoho Zavitu. Translated by P. Kulish, I. Levitskyi, and I. Puliui. Niu York: Amerykanske bibliine tovarystvo, 1944.

Bibliia abo Knyhy Sv. Pysma Staroho ta Novoho Zavitu. Translated by Ivan Ohiienko. VBF "Skhidnoevropeiska misiia", 2018.

Kostiv, Kost. Slovnyk-dovidnyk bibliinykh osib, plemen i narodiv. Kyiv, 1995.

Ostrozka Bibliia. $2^{\text {nd }}$ ed. Edited by yermnkh. arkhimandryt Rafail (Roman Turkoniak). Lviv, 2010.

Triiniak, Ivan. Slovnyk ukrainskykh imen. Kyiv, 2005.

Bibliia. Sviate Pysmo Staroho ta Novoho Zavitu. Translated by o. Ivan Khomenko. Vydavnytstvo Vasyliian: Misioner, 2007.

Janowowa, Wanda, Zaręba, Alfred. Słownik imion. Wrocław, 1991.

\section{Список використаної літератури}

Белей, Любомир. Ім'я для дитини в українській родині. Ужгород, 1993.

Белей, Любомир. «Про соціальне в українській антропонімії». Українська мова $i$ література в школі, № 10, 1990, с. 72-5.

Керста, Розалія. Українська антропонімія XVI cm. Чоловічі найменування. Київ, 1984.

Коваль, Алла. Життя і пригоди імен. Київ, 1982.

Масенко, Лариса. Українські імена і прізвища. Київ, 1990.

Медвідь-Пахомова, Світлана. «Вплив християнства на антропонімійну систему української мови». Християнство й українська мова. Львів, 2000, с. 293-301.

Никонов, Владимир. Имя и общество. Москва, 1974.

Осипів, М. Найголовніше з нового українського правопису. Харків, 1929.

Осташ, Роман. Украинская антропонимия первой половини XVII века. Мужские личные имена (на материале «Реестра Запорожского Войска 1649 г.»). Автореф. дисс. ...канд. филол. наук: 10.02.01. Ужгород, 1986.

Пачичъ, І. Именословъ или ръчникъ личны имена разны народа славенски. Будымъ, 1828.

Сенив, М. И. Украинская антропонимия XIV-XVI вв. (женские именования). Автореф. дисс. ...канд. филол. наук: 10.02.01. Ужгород, 1986.

Супераская, Александра. Структура имени собственного. Фонология и морфология. Москва, 1969.

Фаріон, Ірина. «Вплив християнства на український антропонімікон». Християнство й українська мова. Львів, 2000, с. 302-13. 
Фаріон, Ірина. «Ідентифікаційна функція антропоніма як складник його онтологічної природи». До джерел. Збірник наукових пращь на пошану Олега Купчинського. Київ-Львів, 2004, с. 254-68.

Франко, Іван. «Причинки до української ономастики». Франко І. Твори. В 50 m. Т. 36. Київ, 1982, с. 391-426.

Чучка, Павло. Слов'янські особові імена українців. Історико-етимологічний словник. Ужгород, 2011.

Rospond, Stanislaw. «Struktura pierwotnych etnonimów slowianskich». Rocznik Sławistyczny, т. 26, 1966.

\section{References}

Belei, Liubomyr. Imia dlia dytyny v ukrainskii rodyni. Uzhhorod, 1993.

Belei, Liubomyr. "Pro sotsialne v ukrainskii antroponimii". Ukrainska mova i literatura $v$ shkoli, no 10, 1990, pp. 72-5.

Kersta, Rozaliia. Ukrainska antroponimiia XVI st. Cholovichi naimenuvannia. Kyiv, 1984.

Koval, Alla. Zhyttia i pryhody imen. Kyiv, 1982.

Masenko, Larysa. Ukrainski imena i prizvyshcha. Kyiv, 1990.

Medvid-Pakhomova, Svitlana. "Vplyv khrystyianstva na antroponimiinu systemu ukrainskoi movy". Khrystyianstvo y ukrainska mova. Lviv, 2000, pp. 293-301.

Nykonov, Vladymyr. Ymia y obshchestvo. Moskva, 1974.

Osypiv, M. Naiholovnishe z novoho ukrainskoho pravopysu. Kharkiv, 1929.

Ostash, Roman. Ukrainskaja antroponimija pervoj polovini HVII veka. Muzhskie lichnye imena (na materiale "Reestra Zaporozhskogo Vojska 1649 g."). PhD Thesis Abstract. Uzhhorod, 1986.

Pachichŭ, I. Imenoslovŭ ili rŭchnikŭ lichny imena razny naroda slavenski. Budymŭ, 1828.

Seniv, M. I. Ukrainskaja antroponimija XIV-XVI vv. (zhenskie imenovanija). PhD Thesis Abstract. Uzhhorod, 1986.

Superaskaja, Aleksandra. Struktura imeni sobstvennogo. Fonologija i morfologija. Moskva, 1969.

Farion, Iryna. "Vplyv khrystyianstva na ukrainskyi antroponimikon". Khrystyianstvo $y$ ukrainska mova. Lviv, 2000, pp. 302-13.

Farion, Iryna. "Identyfikatsiina funktsiia antroponima yak skladnyk yoho ontolohichnoi pryrody”. Do dzherel. Zbirnyk naukovykh prats na poshanu Oleha Kupchynskoho. KyivLviv, 2004, pp. 254-68.

Franko, Ivan. "Prychynky do ukrainskoi onomastyky". Franko I. Tvory. 50 vols. Vol. 36. Kyiv, 1982, pp. 391-426.

Chuchka, Pavlo. Slovianski osobovi imena ukraintsiv. Istoryko-etymolohichnyi slovnyk. Uzhhorod, 2011.

Rospond, Stanislaw. "Struktura pierwotnych etnonimów slowianskich". Rocznik Sławistyczny, vol. 26, 1966. 